\title{
Implementasi Pendidikan Karakter Kristiani dalam Merawat Kemajemukan
}

\author{
Ruben Rewasan \\ STT GPI Fakfak Papua \\ bobbygeva@yahoo.com
}

\begin{abstract}
The problem of pluralism in Indonesia is still a hot topic of discussion in society. Even though in formal meetings, most accept pluralism in Indonesia as a gift. However, in reality, in grassroots society, pluralism still faces serious challenges. Perhaps because of this condition, conflicts with a plurality background are still common in Indonesia. In this situation, many people say that the conflicts were triggered by various provocations of elite interests. However, the main problem of various conflicts that occur at the grassroots is because the religious character that characterizes the spirit of pluralism is not well understood. As a result, many people are easily caught up in provocations that tear tolerance. Starting from this fact, instilling a character that accepts and appreciates and implements the spirit of accepting pluralism through a religious education approach is a priority. This is because strengthening a character that is loyal to pluralism is a solid foundation to fend off all forms of provocation that divides the nation. It is also in this interest that character education that is oriented to self-integrity that lives pluralism is the main goal. In this connection, the role of Christian Religious Education is needed in its implementation.
\end{abstract}

Key word: character education, pluralism, Christian religious education.

\begin{abstract}
Abstrak: Masalah kemajemukan di Indonesia masih menjadi perbincangan hangat dalam masyarakat. Walau pun dalam pertemuan-pertemuan formal sebagian besar menerima kemajemukan di Indonesia sebagai anugerah. Akan tetapi dalam kenyataannya pada masyarakat akar rumput, kemajemukan masih mendapat tantangan yang berat. Mungkin karena kondisi ini, konflik-konflik yang berlatar belakang masalah kemajemukan masih sering dijumpai di Indonesia. dalam situasi ini, banyak orang menyebutkan bahwa berbagai konflik itu dipicu oleh berbagai provokasi kepentingan para elit. Namun masalah utama dari berbagai konflik yang terjadi pada akar rumput lebih disebabkan karena karakter keagamaan yang mencirikan spirit kemajemukan tidak dihayati dengan baik. Akibatnya banyak orang dengan mudah terjebak dalam provokasi yang mengoyak toleransi. Bertolak dari kenyataan ini maka menanamkan karakter yang menerima dan menghayati serta mengimplementasikan spirit menerima kemajemukan melalui pendekatan pendidikan agama merupakan prioritasnya. Hal ini disebabkan karena dengan mengokohkan karakter yang loyal terhadap kemajemukan merupakan fondasi kokoh guna menangkis segala bentuk provokasi yang memecah-belah bangsa. Dalam kepentingan ini pula maka pendidikan karakter yang berorientasi pada integritas diri yang menghayati kemajemukan adalah tujuan utamanya. Dalam hubungan ini, peran Pendidikan Agama Kristen sangat dibutuhkan dalam implementasinya. Ini juga yang menjadi tujuan penulisan ini, yaitu sebagai sumbangan untuk menegaskan karakter kristiani yang bercirikan spirit toleran terhadap kemajemukan.
\end{abstract}

Kata kunci: pendidikan karakter, kemajemukan, Pendidikan Agama Kristen.

Article History

\begin{tabular}{|l|l|l|}
\hline Submitted: 5 September 2021 & Revised: 28 Januari 2022 & Accepted: 3 Februari 2022 \\
\hline
\end{tabular}

\section{PENDAHULUAN}

Dalam pidatonya di hadapan prajurit Marinir TNI AL, presiden Republik Indonesia, Ir. Joko Widodo mengatakan "kemajemukan merupakan kekuatan bangsa Indonesia." Dalam arti ini presiden ingin menegaskan bahwa segala hal menyangkut perbedaan di negara ini, baik perbedaan agama, budaya, suku dan latar belakang 
lainnya, merupakan aset yang paling berharga terciptanya keutuhan bangsa Indonesia. Dengan kata lain kemajemukan merupakan anugerah yang menjadikan Indonesia menjadi kuat.

Kendati demikian tidak dapat dipungkiri dalam beberapa waktu belakangan ini, ada semacam kecenderungan dari oknum-oknum tertentu yang memanipulasi isu kemajemukan dan memperalatnya sebagai alat pendongkrak kepentingan politik praktis semata yang tentunya dapat berimbas pada goyahnya keutuhan bangsa Indonesia. Dalam kaitan ini Romo Magnis Suseno pernah menegaskan bahwa tidak sedikit praktisi politik yang karena kepentingan dan ambisi politisnya sering melemahkan kemajemukan. Bahkan propaganda politis yang lebih mengedepankan kemenangan dan kuasa dengan mengabaikan nilai-nilai toleransi merupakan wujud virus berbahaya dalam kemajemukan yang sering dipertontonkan oleh para oknum politisi ambisius beberapa waktu belakangan ini.

Di sisi lain semangat kebangkitan gerakan keagamaan yang eksklusif saat ini cenderung pula mendorong terjadinya gejala penolakan terhadap kemajemukan. Itulah sebabnya tidak mengherankan bila akhir-akhir ini sering dijumpai berbagai gerakan berlabel keagamaan dengan bungkus ayat-ayat Kitab Suci yang dipelintir sebagai pembenaran terhadap eksklusivisme dan menyangkali kekuatan anugerah kemajemukan bangsa Indonesia.

Sebenarnya upaya negara untuk menjaga keutuhan bangsa dalam kemajemukan bangsa sangatlah kuat. Indikasinya tersirat dan tersurat dalam konstitusi negara Indonesia sebagaimana terpapar dalam UUD 1945 dan Pancasila. Di sisi lain penjabarannya sangat jelas dan tegas tercantum pula dalam berbagai produk hukum di Indonesia. Bahkan beberapa hari yang lalu tepatnya tanggal 24 Oktober 2017, rapat paripurna DPR RI telah mengesahkan Peraturan Pemerintah Pengganti Undang-undang (PERPPU) nomor 2 tahun 2017 tentang Organisasi Masyarakat menjadi Undang-undang yang di dalamnya juga mengindikasikan keseriusan negara dalam merawat kemajemukan. Dalam kaitan ini PGI menilai pemerintah sangat konsisten menjaga kemajemukan dalam bingkai Pancasila dan UUD 1945.

Kendati demikian upaya untuk merawat kemajemukan dalam bingkai konstitusi negara, tidak cukup hanya melibatkan peran pemerintah. Semua komponen perlu terlibat aktif menegakkan nilai-nilai luhur kemajemukan sebagai anugerah Tuhan. Konstitusi negara dan segala produk hukum serta undang-undang yang menjiwai semangat kemajemukan harus dihidupkan terus. Salah satu upaya penting untuk 
menghidupkan dan memperkukuh spirit kemajemukan yang selaras dengan jiwa bangsa Indonesia adalah melalui pendidikan karakter. Hal ini disebabkan karena dalam pendidikan karakter setiap individu diarahkan menjadi pribadi yang berkarakter selaras dengan norma-norma agama dan semangat kebangsaan.

Dalam upaya ini melalui pendidikan karakter, penghayatan agama tidak hanya menjadi ranah dogmatis tentang pembenaran superioritas agama. Tetapi lebih dari itu pendidikan karakter akan menjadi pandu dalam mengimplementasikan nilai-nilai agama secara konkret sesuai dengan esensi agama dan konteks dimana agama itu berada. Dalam hubungan ini banyak ahli menunjukan secara jelas bahwa nilai-nilai dan bahasa keagamaan yang dipraktikan dengan baik dan menyentuh aspek kemanusiaan ternyata lebih mudah diterima dan dipahami semua kalangan pemeluk agama. Hal ini disebabkan karena pada hakikatnya semua agama mengajarkan dan menerima segala bentuk nilai-nilai luhur kebaikan sebagai bahasa universal agama (Nuhamara, 2007).

Adapun metode yang digunakan dalam penulisan ini adalah deskriptif kualitatif didasarkan pada amatan langsung dengan referensi buku-buku terkait. Sehubungan dengan alasan ini maka untuk melihat secara teoritik mengenai implementasi pendidikan karakter dalam merawat kemajemukan maka terlebih dahulu kita akan memahami teori mengenai pendidikan karakter dan implementasinya, sebagai berikut:

\section{METODE}

Dalam penelitian ini penulis akan menggunakan metode literatur dalam menemukan pendidikan karakter Kristiani. Literatur yang digunakan berasal dari bidang kajian Pendidikan Agama Kristen. Kemudian penulis akan mengimplementasikan pendidikan karakter tersebut dalam konteks kemajemukan di Indonesia.

\section{HASIL DAN PEMBAHASAN}

\section{Pengertian Karakter}

Menurut Kamus Besar Bahasa Indonesia, karakter diartikan sebagai sifat-sifat kejiwaan, ahklak atau budi pekerti yang membedakan seseorang dengan orang lain. Menurut Kementerian Pendidikan Nasional, karakter adalah cara berpikir dan berperilaku yang menjadi ciri khas setiap individu untuk hidup dan bekerja sama, baik dalam lingkup keluarga, masyarakat, bangsa dan negara. Thomas Lickona memahami karakter sebagai "a reliable inner disposition to respond to situations in a morralay 
good way. Character so conceived has three interrealated parts: moral knowing, moral feeling, and moral behavior" (Lickona, 2013). Sementara itu Keke Aritonang menyebutkan bahwa karakter adalah sifat nyata dan berbeda yang ditunjukan oleh individu (Aritonang, 2007).

Dengan demikian dapat disimpulkan bahwa karakter merupakan totalitas ciri pribadi yang membentuk penampilan seseorang atau obyek tertentu. Ciri-ciri personal mempunyai karakter terdiri dari kualitas moral dan etis; kualitas kejujuran, kebranian, integritas, reputasi yang baik, semua nilai tersebut di atas merupakan sebuah kualitas yang melekat pada kekhasan individu. Itu berarti pula bahwa karakter adalah sesuatu yang telah dipahat dalam hati sehingga merupakan tanda yg khas dimana karakter mengacu pada moralitas kehidupan sehari-hari. Karakter bukan merupakan kegiatan sesaat, melainkan kegiatan konsisten muncul baik secara batiniah dan rohaniah. Karakter mengacu pada kebiasaan berpikir, berperasaan, bersikap, berbuat, membentuk tekstur dan motivasi kehidupan seseorang. Karakter erat dengan pola tingkah laku, kecenderungan pribadi untuk berbuat baik. Itulah sebabnya karakter sebagai suatu aspek penting dan melekat pada personal yang berisi totalitas ide, aspirasi sikap, yang terdapat dalam individu dan telah mengkristal pada pikiran dan tindakan haruslah dikenali oleh setiap individu (Sidjabat, 2010).

\section{Selayang Pandang: Memahami Kemajemukan dan Dampaknya}

Kemajemukan masyarakat adalah perbedaan warga masyarakat ke dalam kelompok-kelompok secara horizontal. Masyarakat majemuk sering disebut masyarakat pluralistik atau diferensiasi sosial. Konsep masyarakat ini sangat penting untuk memahami karakter dan dinamika masyarakat Indonesia. Adanya perbedaanperbedaan itu akan mempengaruhi kesetabilan masyarakat atau bangsa Indonesia. Perbedaan ras dan etnis merupakan faktor yang dominan dalam membentuk kemajemukan sosial budaya masyarakat. Disamping itu terdapat faktor yang lain yaitu faktor agama/kepercayaan.Karena faktor ras dan etnis sangat dominan pengaruhnya terhadap masyarakat, maka masyarakat yang majemuk sering disebut "masyarakat multi ras" atau "multi etnis". Ada pun beberapa faktor terbentuknya kemajemukan masyarakat Indonesia disebabkan karena:

1. Kondisi wilayah Negara kesatuan Republik Indonesia yang terdiri kurang lebih 17.058 buah pulau besar dan kecil berkembang melahirkan keragaman budaya.

2. Letak wilayah Indonesia yang strategis pada posisi silang sehingga memungkinkan terjadi kontak dengan bangsa-bangsa lain. Akibat pertemuan 
dengan pendatang menyebabkan tercipta proses asimilasi melalui perkawinan campuran (amalgamasi) sehingga terbentuk ras dan etnis.

3. Perbedaan iklim dan topografi diantara daerah satu dengan daerah lainnya mengakibatkan terbentuknya aneka budaya kelompok masyarakat.

4. Kemajemukan masyarakat Indonesia juga disebabkan oleh bebarapa hal yang dapat dilihat antara lain berdasarkan Ras, Etnis dan Agama.

Seperti telah ditegaskan pada bagian awal, kemajemukan di Indonesia merupakan anugerah yang dapat memperkukuh kekuatan bangsa. Kendati demikian, bila tidak dirawat dengan benar, kemajemukan dapat dipelintir, dijadikan alat pembenaran konflik dalam memecah-belah persatuan dan kesatuan bangsa. Dalam wujudnya dapat berupa konflik tertutup semacam perang urat syaraf berlatar belakang SARA yang kini cukup marak dalam media sosial. Konflik pun bisa berbentuk konflik terbuka berupa bentrokan fisik, perang mulut atau perang kata-kata secara terbuka yang tidak jarang dibumbui dengan kata-kata kasar tak bermoral.

Bila kondisi ini dibiarkan maka segala bentuk konflik tersebut dapat berkembang, bukan saja berupa konflik antar pribadi, atau antar individu tertentu. Imbasnya konflik-konflik tersebut akan berkembang menjadi konflik antar kelompok dalam kelompok sosial, antar pendukung politik, antar ras, bahkan antar agama yang ujung-ujungnya bisa berkembang menjadi pertikaian terbuka. Bahkan di beberapa tempat di Indonesia sendiri pernah mengalami terjerembab dalam konflik-konflik tersebut. Kondisi seperti ini sudah barang tentu merugikan kehidupan banyak orang. Bukan saja orang akan mengalami kerugian secara materi. Terlebih dari itu korban jiwa, kelumpuhan ekonomi serta hancurnya kewibawaa bangsa Indonesia akan menjadi taruhan dari semua konflik-konflik yang tidak ada gunanya. Terlebih dari itu konflik-konflik berbau SARA yang berimbas pada tindakan yang merugikan nilai-nilai kemanusiaan sangat bertentangan dengan nilai-nilai esensi keagamaan.

\section{Pendidikan Karakter Sebagai Salah Satu Jawaban Merawat Kemajemukan}

Pendidikan karakter bersifat luas dalam cakupan dan sulit didefinisikan secara tepat. Tetapi, yang dimaksud pendidikan karakter di sini adalah suatu istilah yang menjelaskan berbagai aspek pengajaran dan pembelajaran bagi perkembangan personal. Pendidikan karakter meliputi beberapa area, seperti: penalaran moral dan pengembangan kognitif, pembelajaran sosial dan emosional, pendidikan dan kebajikan moral, pendidikan keterampilan hidup; pendidikan kesehatan, pencegahan kekerasan, resolusi konflik, dan filsafat etik dan moral. 
Dalam ranah tersebut, pendidikan karakter menggarap pelbagai aspek dari pendidikan moral, pendidikan kewarga negaraan, dan pengembangan karakter. Sifatnya yang multi-faceted membuatnya menjadi konsep yang sulit untuk diberikan di sekolah. Setiap komponen memberikan perbedaan tekanan tentang apa yang penting dan apa yang semestinya diajarkan. Oleh karena itu jika pendidikan karakter mencapai tujuannya maka sepatutnya mesti ada satu bahasa global wacana publik yang mempertanyakan "apa yang benar" (what's right?) (Kidder, 1995). Bahasa ini merupakan bahasa yang unik yang membuat banyak orang tidak terlalu nyaman membincangkannya. Untuk membuat manusia nyaman berbincang dalam bahasa ini di masa depan, Kidder menekankan perlunya pendidikan karakter sejak dini. Pendidikan karakter dapat dimulai dari ranah pendidikan formal mulai sejak usia dini. Mengucapkan terima kasih atau sekadar menyapa adalah bagian (latihan) dalam pendidikan karakter. Kelihatan sederhana memang, tetapi sekarang pun jarang ditemukan orang yang rela berucap terima kasih atau sekadar menyapa dengan senyum. Pendidikan karakter tidak perlu harus dinilai secara kognitif. Desain pendidikan karakter seharusnya jauh dilepaskan dari unsur penilaian kognitif. Salah satu kegagalan pembentukan karakter saat ini karena terlalu mengkognitifkan nilainilai dalam pembentukan karakter.

Dalam pendidikan karakter, para siswa ini disiapkan untuk mampu menyikapi pilihan hidup dengan bijak. Namun, sekolah bukanlah satu-satunya tempat yang utama. Masih ada keluarga dan masyarakat. Rumah dan masyarakat mampu menjadi sahabat, tapi dapat pula menjadi penyekat apabila tidak ada empati yang dirasakan. Semua individu adalah pelaku pendidikan karakter. Dalam lingkungan sekolah, pendidikan karakter harus dimulai dari guru. Guru bukan hanya mengajarkan pelajaran karakter, tetapi guru harus mampu menempa dirinya agar berkarakter. Siswa bukan barang mati yang dapat diperdaya dengan berbagai contoh baik, tetapi guru tidak melakukan hal itu.

Pendidikan karakter mengedepankan contoh dan perilaku daripada ilustrasi angka yang mereduksi hakikat karakter sendiri. Materi pendidikan karakter dipahamkan melalui kegiatan belajar mengajar dalam metode, dan bukan ditagihkan melalui tes. Guru tidak lagi harus duduk di meja sambil membaca buku atau menikmati tontonan presentasi siswa. Dalam hal ini tugas utama adalah harus mampu menjadi inspirator setiap siswa dalam belajar. Demikian juga, dalam mata pelajaran adalah sarana yang menjembatani antara guru dan siswa dalam berelasi. Guru tidak mungkin 
lepas dari materi pelajaran. Guru juga harus mampu mengembangkan materinya sehingga mampu melahirkan kebiasaan diskusi dan eksplorasi akademis.

Karakter dapat diolah melalui berbagai aktivitas yang didasari dengan sikap moral yang benar. Dalam implementasinya, siswa harus diberikan kesempatan sebanyak mungkin untuk mengekspresikan dirinya. Hal ini penting untuk penyaluran emosional. Aktivitas belajar di kelas dengan jadwal yang ketat membuat siswa menjadi lemah kreasi. Kebiasaan nongkrong di luar sekolah terjadi karena tidak ada ruang ekspresi bagi siswa di sekolah. Anggapan yang muncul bahwa sekolah favorit adalah sekolah dengan kemampuan kognitif tinggi tidak sepenuhnya benar. Kognitif tinggi tanpa disertai karakter yang baik akan menghasilkan siswa dalam cangkang-cangkang akademis yang minus nurani. Saluran emosional sangat penting dalam ranah pendidikan karakter. Keuntungan lain dari ekspresi adalah mampu menghargai perbedaan orang lain atau kultur lain tanpa harus mengerutkan dahi. Melatih siswa berpikir kritis sangat penting adalah bagian selanjutnya. Berpikir kritis akan menghasilkan sikap keberpihakan. Hal ini dapat dilakukan dengan berdiskusi atau berdebat di kelas. Berpikir kritis dengan model debat untuk melatih siswa mampu mendengarkan argumen atau opini orang lain. Debat bukan melatih siswa asal berpendapat, tetapi memberi kesempatan saling mencermati. Sayangnya, kurikulum pendidikan di Indonesia masih belum menyentuh aspek karakter ini, meskipun ada pelajaran pancasila, kewarganegaraan, akhlaq dan semisalnya, tapi itu masih sebatas wacana dan tidak dalam tataran aplikatif.

Menurut pedagog Jerman FW Foerster, seorang pencetus pendidikan karakter, ada empat ciri dasar dalam pendidikan karakter. Pertama, keteraturan interior di mana setiap tindakan diukur berdasar hierarki nilai. Nilai menjadi pedoman normatif setiap tindakan. Kedua, koherensi yang memberi keberanian, membuat seseorang teguh pada prinsip, tidak mudah terombang-ambing pada situasi baru atau takut risiko. Koherensi merupakan dasar yang membangun rasa percaya satu sama lain. Tidak adanya koherensi meruntuhkan kredibilitas seseorang. Ketiga, otonomi. Di situ seseorang menginternalisasikan aturan dari luar sampai menjadi nilai-nilai bagi pribadi. Ini dapat dilihat lewat penilaian atas keputusan pribadi tanpa terpengaruh atau desakan pihak lain. Keempat, keteguhan dan kesetiaan. Keteguhan merupakan daya tahan seseorang guna mengingini apa yang dipandang baik. Dalam arti ini kesetiaan merupakan dasar bagi penghormatan atas komitmen yang dipilih. Kematangan keempat karakter ini, lanjut Foerster, memungkinkan manusia melewati tahap individualitas menuju personalitas. 


\section{Implementasi Peran Agama dalam Pembentukan Karakter}

Membicarakan agama dalam kohesi sosial atau kajian fungsional atas agama yaitu hubungan antara agama dengan sub sistem yang lain, ada tujuh hal yang disebut oleh O'Dea mengenai fungsi agama yaitu; “Pertama: agama merujuk suatu apa yang ada di luar, ia dapat menjadi semangat atau suport, memberi hiburan (pengharapan) dan rekonsiliasi. Manusia memerlukan suport dalam menghadapi masa depan yang tidak pasti, memberikan pengharapan untuk berjalan dengan iman, atau hiburan ketika menghadapi kekecewaan, dan rekonsiliasi dengan masyarakat bila mengalami keterpencilan dari tujuan dan norma sosial. Kedua; agama memberikan hubungan transendental melalui upacara-upacara persembayangan sehingga memberikan rasa aman dan identitas yang kokoh dalam menghadapi perubahan. Ketiga; agama mensakralkan norma dan nilai dalam masyarakat, menjaga kelestarian dominasi tujuan dan disiplin kelompok atas keinginan dan dorongan-dorongan individual (sebagai sosial kontrol). Keempat: agama sebagai kritik sosial, dimana norma-norma yang sudah melembaga ditinjau ulang, sesuai dengan fungsi kenabiannya (prophetic agama). Kelima; agama memberikan identitas dan menyadarkan tentang "siapa" mereka dan "apa" mereka. Keenam: agama berfungsi dalam hubungannya dengan kematangan seseorang individu dalam masyarakat. Ketujuh; agama berfungsi dalam membentuk social solidarity (solidaritas sosial) dan terakhir agama dapat berperan dalam pemerataan pendapatan.

Jadi kajian fungsi agama sangat berperan dalam memembentuk watak dan karakter bangsa, nilai-nilai agama bisa memberi semangat bagi individu dan kelompok masyarakat dalam menghadapi krisis multidimensional yang tak kunjung selesai, menghadapi disintegrasi bangsa, korupsi kolusi dan nepotisme (KKN) yang menggurita.Termasuk di dalamnya menghadapi isu intoleransi sebagai penyebab utama pecahnya semangat kemajemukan yang pada akhir-akhir ini ramai dibicarakan. Nilai-nilai agama memberi penghiburan dan harapan untuk menghadapi ketidak pastian serta memberi keyakinan bahwa pada saatnya krisis akan berakhir dan bangsa bisa bersatu mewujudkan tujuan nasionalnya. Tegasnya pendidikan agama dapat memberi semangat (suport) memberi hiburan dan rekonsiliasi. Manusia perlu suport menghadapi masa depan, harapan dalam iman, hiburan ketika kecewa. Dalam hal ini sumbangsih pendidikan agama dapat terwujud dalam bentuk-bentuk sebagai berikut:

a. Hubungan transendental melalui upacara persembayangan, merasa aman, identitas yang kokoh dalam menghadapi perubahan. 
b. Agama mensakralkan norma yang berfungsi ebagai sosial kontrol.

c. Sebagi kritik sosial dimana norma yang ada ditinjau ulang, sesuai fungsi kenabiannya.

d. Memberi identitas; menyadarkan tentang siapa, mereka dan apa mereka.

e. Sebagai sarana pembentuk solidaritas sosial.

Dalam mensosialisasikan pembentukan karakter melalui Pendidikan agama Kristen di masyarakat perlu dikembangkan nilai-nilai kebersamaan. Hal yang sangat penting dalam mengembangkan hidup bersama sebagai warga bangsa adalah menanamkan nilai-nilai toleransi antar umat beragama, bahwa bangsa Indonesia merupakan masyarakat yang majemuk dan heterogen. Sikap saling menghormati dan mengharagai perbedaan yang ada harus senantiasa dikembangkan. Oleh karena itu sikap eksklusif dan pemahaman terhadap agama yang sempit dengan menjadikan agama sebagai alat legitimasi untuk melakukan kekerasan terhadap pemeluk agama lain harus dihindari. Tindakan antagonis ini sangat counter producitive dengan hakikat kemanusiaan universal.

Pemahaman agama yang berada dalam tataran institusi, hanya menghasilkan hal yang formalitas, dan belum mengenai makna yang esensial. Sedang pemahaman makna yang esensial, nilai-nilai agama akan dapat dijadikan motivasi kebersamaan, kesetaraan dalam berbangsa dan bernegara. Oleh karena itu sangat penting artinya pendidikan karakter lewat pendidikan agama bagi generasi muda, maka nilai agama tidak hanya sebagai ritualitas tetapi diharapkan dapat mengutamakan nilai-nilai kemanusiaan. Penghayatan dan pengamalan nilai-nilai agama secara baik akan memperkuat nilai-nilai kemanusiaan, dan dapat dijadikan landasan spiritual, moral, etika bagi pembangunan nasional, sehingga dapat memperkokoh kesatuan dan persatuan bangsa

\section{Kasih yang Tulus Sebagai Dasar Pembentukan Karakter}

Menurut Hartoyo nilai-nilai subtansial sebagai akar budaya masyarakat sipil di Amerika dan Eropa Barat adalah nilai kasih yang diimplementasikan dalam segala aspek kehidupan manusia. Sebagai contoh orang Barat sangat patuh sekali dalam tatatertib berlalu lintas, karena pada prinsipnya jika melanggar berarti akan menyusahkan orang lain. Di negeri barat juga dijunjung tinggi nilai-nilai kehidupan orang lain atau sangat menghargai perbedaan dan pendapat orang lain sebagai wujud dari masyarakat sipil. Selaras dangkan hal ini, Sangadi Mulya mengetakan bahwa peran orang Kristen dalam mewujudkan masyarakat sipil adalah sebagai garam dan 
terang yang menggarami dalam segenap hidup manusia. Prinsip Kekristenan adalah ibadah yang holistik tidak hanya ibadah ritual tetapi diterapkan dalam segenap aspek kehidupan manusia sehingga menghasilkan buah yang nyata menjadi berkat bagi orang lain. Contoh konkret "Pelayanan Kristiani" telah dilakukan oleh Almarhum Ibu Theresia dari India, Almarhum Yohanes Leimena, Yos Sudarso, Romo YB Mangun Wijoyo yang memiliki kepekaan sosial terhadap lingkungannya dengan memberikan hidupnya untuk masayarakat marginal. Nilai-nilai ini dapat diwujudkan dengan mendasarinya pada Injil sebagai kekuatan Allah yang menghidupkan dan memberikan kemampuan, kesanggupan dan kekuatan bagi penganutnya. Karena itu pembentukan karakter sangat perlu didasari oleh kekuatan Alkitab. Apalagi dengan sangat jelas indikasinya tergambar di dalamnya. Berikut ini beberapa spirit yang digambarkan oleh Alkitab sebagai acuan pembentukan karakter, yaitu:

1) Moderat dan merenungkan firman Tuhan siang dan malam Mazmur 1.

2) Menstranfer nilai berulang-ulang. Mengimplementasikan dalam kehidupan sehari-hari Etika Kristen.

3) Prinsip peserta didik harus diberi kesempatan untuk menjadi pelaku firman, aktif secara fisik dan mental. Firman itu harus menjadi daging.

4) Yesus memberi teladan lintas SARA (orang samaria yang baik hati) dalam mengasihi sesama secara totalitas, oleh karena itu pendidikan pluralisme penting untuk membawa kabar damai melalui pendidikan karakter. Adapun karakter yang ditampilkan oleh Yesus yang dapat dijadikan sebagai acuan adalah bahwa Yesus peduli, sakit disembuhkan, lapar dicukupkan, mati dibangkitkan, lumpuh berjalan, buta melihat, Menolak agama Verbalistik, formalisme, iman dan perbuatan.

\section{Sekali lagi Tentang Peran Guru PAK Sebagai Implementator Terpenting}

Tidak dapat dipungkiri bahwa pendidik atau guru merupakan salah satu faktor utama dalam tercapainya tujuan pendidikan si sekolah. Dalam hal ini seorang pendidik harus dengan benar memahami peran dan fungsinya dalam pembentukan karakter peserta didik. Utamanya, pendidik bukan hanya sekedar berteori tetapi ia adalah teladan. Dalam paparan ini akan disampaikan aspek-aspek yang berkait dengan pendidik atau guru sebagai alat yang digunakan oleh Tuhan dalam membentuk karakter peserta didik.

Syarat pertama dalam pembentukan karakter siswa bagi seorang pendidik atau guru adalah bahwa ia harus memiliki kualifikasi rohani yang baik. Terutama adalah ia 
harus memahami bahwa dirinya sebagai seorang Kristen yang dipakai oleh Allah. Ketika Guru memahami dirinya sebagai seorang Kristen, dimana seorang Kristen harus mampu memberi dirinya secara penuh kepada Kristus maka sebagai Pendidik Kristen, ia harus rela berkorban, mampu menajadi pengajar sesuai teladan yang telah diberikan oleh Tuhan Yesus. Bagaimana sikap seorang Kristen? Orang Kristen ialah orang yang percaya dan menyambut sepenuhnya kedudukan dan peran Yesus sebagai Tuhan, Juruselamat dan Raja atas kehidupannya. Dengan demikian maka kualifikasi rohani pendidik agama Kristen adalah mampu merespon dan meneladani kehidupan Kristus dengan sungguh-sungguh serta membuka diri untuk didiami oleh Roh Kudus, sebagai penuntun dan penolong dalam melakukan tugas dan tanggung jawab sebagai seorang Guru. Kedua, mampu memahami tugas dan tanggungjawab sebagai guru dalam melaksanakan Tugas keguruan. Sebagai orang Kristen, guru terpanggil untuk bertumbuh kearah pengenalan yang semakin mendalam dan lengkap tentang pribadi Yesus Kristus. Pengenalan tentang pribadi Yesus adalah jalan, kebenaran, dan hidup, membawa orang kepada pengenalan yang sejati akan karya Allah. dalam Yoh. 1:18, jelas bahwa, Yesus menyatakan dengan tegas bahwa di luar Dia, orang tidak dapat melakukan hal yang benar bagi kemuliaan Allah. melalui persekutuan dengan Kristus, seorang pendidik agama Kristen semakin menemukan kebenaran yang sesungguhnya. Kebenaran yang dinyatakan Allah kepada setiap orang percaya menyangkut segi kognitif (intelek-pemikiran), segi moral, etis, serta spiritual. Selain itu kebenaran yang harus dikejar oleh Guru Kristen adalah kebenaran realistis, yaitu yang nyata dalam kehidupan. Pendidik agama Kristen, mampu mengajar sesuai kebenaran Alkitab dan apa yang hendak diajarkan bukan hanya sekedar pengetahuan seorang guru tetapi perlu tindakan dan memberi keteladanan (Rewasan, 2013). Karena seorang pendidik Agama Kristen yang ingin menanamkan karakter Kristiani kepada muridnya maka ia perlu memiliki kualifikasi rohani yang meliputi:

1) Mengenal Tuhan Yesus: Seorang pendidik anak bertanggungjawab mengenalkan Tuhan Yesus kepada anak-anak. Dalam hal ini amat penting seorang pendidik mengenal Tuhan Yesus secara pribadi. Dengan demikian maka guru Kristen memiliki dasar yang kokoh untuk memperkenalkan karakter Kristus kepada anak didiknya.

2) Mengenal Firman Tuhan: Seorang pendidik, akan membutuhkan waktu untuk membaca Firman Tuhan setiap hari. Hidup rohani seorang pendidik akan diubah dan berkembang jika menyukai firman Allah dan menjadikan firman itu 
bagian dari hidupnya sehari-hari. Jika seorang pendidik hanya membaca Alkitab sesaat sebelum ia mengajar, dia akan kekurangan kewibawaan rohaninya. pendidik yang kurang memiliki waktu saat teduh bersama dengan Tuhan, dapat dirasakan oleh anak-anak. kesediaan dan sukacita dalam mengenal firman Tuhan, akan membawa kewibawaan dalam mengajar. Bila demikian pendidik dapat mengajar tanpa dibuat-buat. Apa yang dia lakukan akan mengalir dengan wajarnya, ia mengajar berdasarkan pengenalan Kristus.

3) Menjadi teladan rohani Terhadap murid, rekan Guru bahkan Masyarakat Umum: Peserta didik tidak hanya akan terkesan dengan apa yang dikatakan oleh pendidik, tetapi bagaimana guru juga hidup sesuai dengan apa yang dikatakannya itu. Artinya seorang guru Kristen tidak hanya mampu mengajar kepada anak-anak agar mengasihi, saling menolong, sementara dirinya sendiri sebagai pengajar, tidak dapat mengasihi dan menolong. Untuk itu, seorang pendidik Kristen, tidak hanya seorang yang intelektual yang memiliki banyak pengetahuan, tetapi pengetahuan akan firman Tuhan harus sesuai dengan tindakannya sehingga dapat disebut profesional.

4) Menghargai Anak: Seorang pendidik akan melihat peserta didik dengan kasih sayang Tuhan Yesus. la mengerti bahwa setiap anak berharga dihadapan Allah. Karena itu, anak juga berharap untuk dia. Pendidik akan paham bahwa apa yang dia lakukan untuk anak-anaknya, dia perbuat juga bagi Tuhan Yesus. Dalam hal ini, seorang guru Kristen tidak pilih kasih, tetapi memandang semua anak sama dan diperlakukan sama untuk diperhatikan dan diajar penuh kasih sayang.

Selain beberapa kualifikasi tersebut di atas, pendidik Kristen juga harus mampu bertanggungjawab dengan tujuan pendidikan pengajaran Agama itu sendiri. Menurut Homrighausen, tanggungjawab guru Kristen adalah:

"Menjadi penafsir iman Kristen, dialah yang menguraikan kepercayaan Kristen itu karena ia harus menyampaikan harta dari masa lampau kepada para pemuda yang akan menempuh masa depan. Guru juga menjadi seorang gembala bagi muridnya, bertanggungjawab atas hidup rohani mereka, ia wajib membina dan memajukan hidup rohani itu. Guru harus juga menjadi pedoman dan pemimpin, ia tidak boleh menuntun muridnya masuk kedalam kepercayaan Kristen dengan paksaan, melainkan ia harus membimbing mereka dengan halus dan lemah lembut kepada juruselamat dunia (Homrighausen \& Enklaar, 2013). 
Dengan memahami pernyataan dari Homrighausen ini, sangatlah tegas bahwa seorang pendidik agama Kristen harus mampu mempraktikkan rohaninya di tengahtengah para murid, bahkan juga di komunitas orang percaya. Akhirnya, pendidik adalah seorang penginjil maka ia bertanggungjawab atas penyerahan diri setiap orang pelajarnya kepada Yesus Kristus. Belum cukup jikalau ia menyampaikan mereka segala pengetahuan tentang Kristus. Tujuan pengajaran itu adalah supaya mereka sungguh-sungguh menjadi murid-murid Tuhan Yesus, yang rajin dan setia.

\section{KESIMPULAN}

Pendidikan karakter dapat menjadi media penting dalam merawat kemjemukan di Indonesia. Dalam hal ini pendidikan karakter menjadi sebuah model pendidikan yang mempertegas bahasa universal agama, yaitu menjadi semacam jembatan untuk mempertegas bahasa dogmatis ke dalam nilai-nilai kebaikan beralaskan ke-Tuhan-an

\section{Yang Esa dan hakikat kemanusiaan.}

Sudah barang tentu, dalam implementasinya semua pihak terlibat. Bukan saja guru di sekolah tetapi juga lembaga agama, lembaga adat, pemerintah. Utamanya memaksimalkan peran orang tua. Dalam implementasinya semua pihak menjabarkan nilai-nilai keagamaan dalam wujud kebaikan konkrit. Santun, berbudi pekerti, bermoral, penuh cinta kasih, menghargai perbedaan, menjauhi segala bentuk kekerasan dan intimidasi, merupakan wujud nyata model pendidikan karakter yang harus benar-benar dinyatakan: ia bukan hanya menjadi slogan, konsep atau teori belaka. Tegasnya pendidikan karakter harus dihidupkan dalam kehidupan nyata.

\section{DAFTAR PUSTAKA}

Aritonang, K. (2007). Upaya Mengembangkan Sikap Siswa Melalui Nilai dan Moral. Jurnal Pendidikan Penabur, 8(7).

Homrighausen, E. G., \& Enklaar, I. H. (2013). Pendidikan Agama Kristen. BPK Gunung Mulia.

Kidder, R. (1995). How Good People Make Tough Choices. Harper Collins Publisher Lickona, T. (2013). Pendidikan Karakter Panduan Lengkap Mendidik Siswa Menjadi Pintar dan Baik. Nusa Media.

Nuhamara, D. (2007). Pembimbing PAK. Jurnal Info Media.

Rewasan, R. (2013). Buku Ajar Administrasi PAK. STT GPI Papua.

Sidjabat, B. S. (2010). Spiritualitas dan Pembentukan Karakter. Jurnal Pengarah. 